\section{Novel Approach for Predicting Direct and Open Solar Drying Using Artificial Neural Network for Medicinal Plant}

\author{
A. Sadadou, S. Hanini, M. Laidi, ${ }^{*}$ and A. Rezrazi
}

Biomaterials and Transport Phenomena Laboratory, University of Yahia Fares Médéa, Algeria
https://doi.org/10.15255/KUI.2020.049

KUI-12/2021

Original scientific paper

Received July 13, 2020

Accepted August 26, 2020

\begin{abstract}
In this study, an artificial neural network (ANN) was developed to obtain a generalized model for predicting the direct and open sun drying process for some medicinal plants. Since the quality of the experimental dataset can lead to a very performant model, in this study the dataset was collected from previously published papers and divided randomly into three subsets, namely $70 \%, 15 \%$, and $15 \%$ for training, testing, and validation. Based on the complex solar drying behaviour, ten parameters were considered as inputs: time, global solar radiation (GSR), outside temperature, inclination, emissivity, altitude, longitude, latitude, inside temperature, and nutritional value, to predict moisture content (MC), and drying rate (DR). Based on a trial and error method, the best ANN model was found with a topology of 10-28-14-2, with regression coefficient and root mean square error of $(R=97.044 \%$. RMSE $=4.589 \%)$ and $(R=99.968 \%$, RMSE $=1.185 \%)$ for MC and DR, respectively. It can be concluded that the obtained ANN model provides the best method for solar dryer modelling which can be generalized for any location in the world.
\end{abstract}

\title{
Keywords
}

Artificial neural network, medicinal plant, solar drying, moisture content, drying rate

\section{Introduction}

In many agrarian countries, large quantities of food products are dried in the aim of improving shelf life, reducing packing costs, lowering shipping weights, enhancing appearance, encapsulating the original flavour, and maintaining the nutritional value. ${ }^{1}$ Moreover, drying is the most common and fundamental method for the post-harvest preservation of medicinal plants, because it allows for a quick conservation of the medicinal qualities of the plant material in a simple manner. Different solar equipment has been used for medicinal plant products drying. Reported in literature are optimisation and modelling of such a complex process using different linear and non-linear modelling techniques, namely artificial intelligence algorithms like artificial neural networks (ANN).

Recently, the ANN technique has attracted the interest of researchers because of modelling complex problems. Many authors have investigated the use of an ANN to model artificial and solar drying behaviours. For example, one study ${ }^{2}$ used an ANN to predict the temperature variation of a food product during solar drying, while another ${ }^{3,4}$ used an ANN to predict the hourly mass of jaggery during the process of drying inside a greenhouse dryer under the natural convection mode. In addition, ANNs have been used to study the drying of cooked rice, ${ }^{5}$ Siirt pistachios, ${ }^{6}$ apples, ${ }^{7}$ Artemisia absinthium ${ }^{8}$ seedy grapes,${ }^{9}$ agricultural products, ${ }^{10}$ and sweet potatoes. ${ }^{11}$ Only a few studies have used ANNs to study agricultural solar drying with the majority focusing on artificial drying.

* Corresponding author: Dr Maamar Laidi

Email: maamarw@yahoo.fr
The main objective and novelty of this study is to model the solar drying process of different types of medicinal plants. This model is optimised using a dataset governing different geographic coordinates, climates, and drying mode, especially direct solar drying and open sun drying.

\section{ANN structure}

An ANN is a data processing mathematical model. It consists of numerous units or elements called nodes or neurons. These neurons are interconnected in structured layers, with weights and biases between the layers. The first layer is called the input layer, which depends on the number of input variables, and the last layer is called the output layer, which depends on the number of desired outputs from the model. The layers between the input and output are known as hidden layers. Usually, three stages are considered in ANN construction: (i) training, (ii) validation, and (iii) testing. During the training and validation stages, both input and target data are introduced to the network. However, in the testing stage, a different set of data containing only input values is fed to the network. ${ }^{12}$ An MLP network algorithm was used in this study. This network consisted of three or more layers, depending on the selected performance, an input layer containing ten neurons, one or more hidden layers with a variable number of neurons, and an output layer containing two neurons. Two phases were used to train a back-propagation network: a forward pass phase, during which information processing occurred from the input layer to the output layer, and a backward pass phase, where the error from the output layer was propagated back to the input layer, and the interconnections 


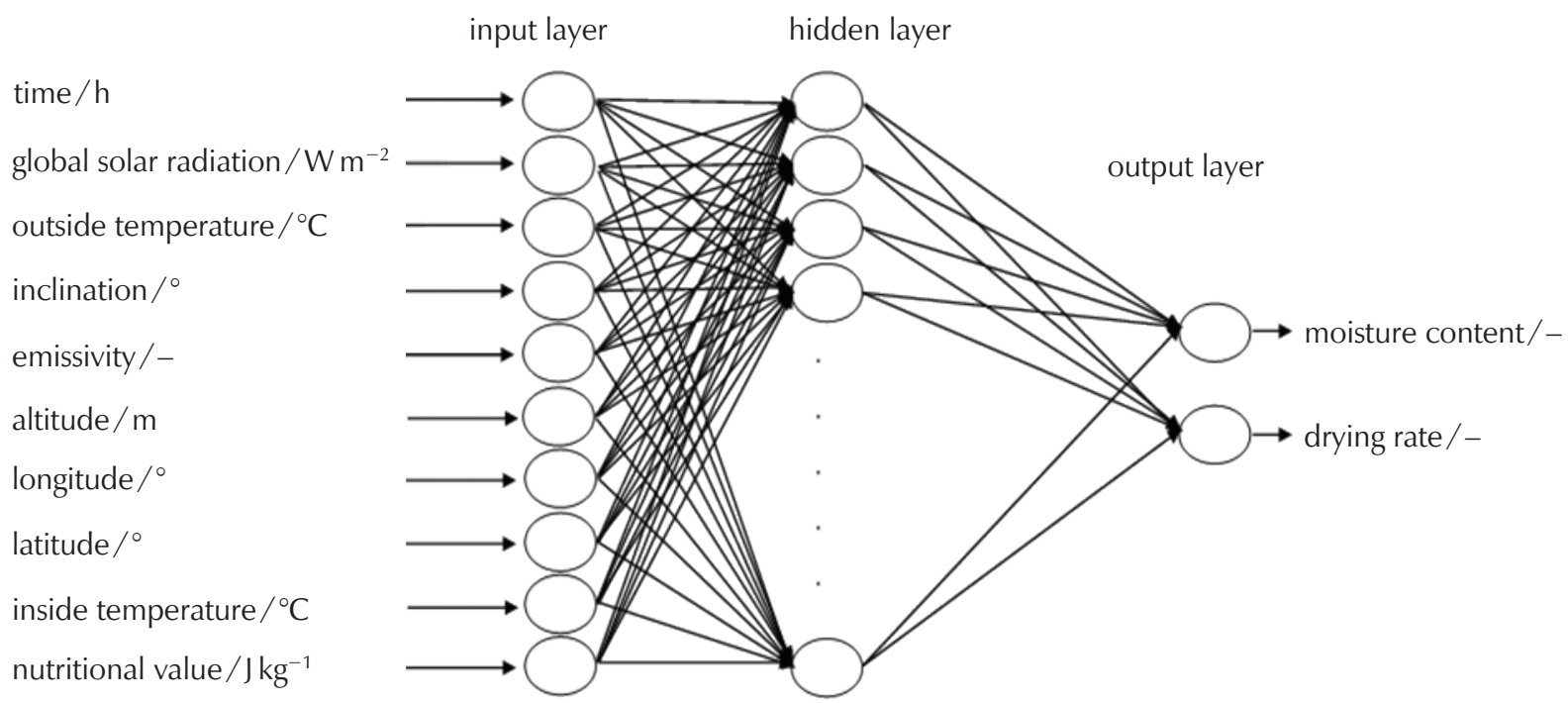

Fig. 1 - Schematic presentation of the proposed MLP network with single hidden layer

were modified. ${ }^{13}$ This algorithm adjusted the connection weights based on the back-propagated error computed between the observed and estimated results. ${ }^{14-17}$ This was a supervised learning procedure that attempted to minimize the error between the desired and predicted outputs. The general structure of the obtained ANN is shown in Fig. 1.

\section{Dataset collection}

The data used in the current study, $\{804$ points, 12 parameters\}, were collected from published experimental studies on the solar drying of medicinal plants all around the world. The selected inputs were time, outside temperature, global solar radiation, inside temperature, inclination, emissivity, attitude, latitude, longitude, and nutritional value, while MC and DR were used as outputs. The training/ validation set contained 724 data, and 80 data for testing. This was performed by the elaboration of a MATLAB program to test and optimise all ANN parameters. Table 1 summarizes the used products along with the number of points, sources, and place. The datasets were extracted from the experimental curves under some assumptions like the emissivity of the cover surface of the drying system, which was equal to one when dried product was exposed directly to the sun without a cover elsewhere, and when the dried product was covered by a material such as plastic, wood, or glass, we took the emissivity value off the cover material. The inclination angle of the solar dryer was considered as the latitude of the geographical location in a case where the product was above a horizontal surface ${ }^{18}$ and aiming to capture the maximum radiation. In addition, for temperature, two values were used, the inner and outer system drying values. When the dried product was directly exposed to the sun (no cover), these temperature values were equal. The nutritional value was used to distinguish between dried products. ${ }^{19-21}$
Table 1 - Sources of medicinal plant dataset

\begin{tabular}{|c|c|c|c|}
\hline Source & $\begin{array}{c}\text { Nature of the } \\
\text { product }\end{array}$ & $\begin{array}{c}\text { Number of data } \\
\text { points }\end{array}$ & Country \\
\hline 22 & Mint & 14 & Elazig, Turkey \\
\hline \multirow{4}{*}{23} & Henna & 56 & \multirow{4}{*}{ Ismailia, Egypt } \\
\hline & Rosemary & 92 & \\
\hline & Marjoram & 60 & \\
\hline & Moghat & 144 & \\
\hline 24 & Mint & 114 & Giza, Egypt \\
\hline \multirow{3}{*}{25} & Mint & 108 & \multirow{3}{*}{$\begin{array}{l}\text { Bouzareah, } \\
\text { Algeria }\end{array}$} \\
\hline & Verbena & 108 & \\
\hline & Laurel & 108 & \\
\hline
\end{tabular}

\section{Results and discussion of artificial neural networks modelling}

Trial-and-error method ${ }^{26}$ was used to select the best feed-forward back-propagation ANN model. For that, several configurations were tested by changing the training algorithms, transfer functions \{logistic sigmoid, tangent sigmoid and linear\}, learning rate which determines the size of the weight adjustment each time during the training stage, and the momentum term which is used to increase the speed of network. ${ }^{27}$ Generally, for one or two hidden layers, the best learning rate and momentum $(\mathrm{m})$ are $\sim 0.2$ and $0.3<m \leq 0.5 .^{28}$ The dataset was scaled between $[-1,1]$ using MATLAB function premnmx.

The accuracy of the developed models was measured using different statistical parameters like mean absolute deviation (MAD), sum squared error (SSE), mean squared error (MSE), root mean squared error (RMSE), and mean absolute percentage error (MAPE). 


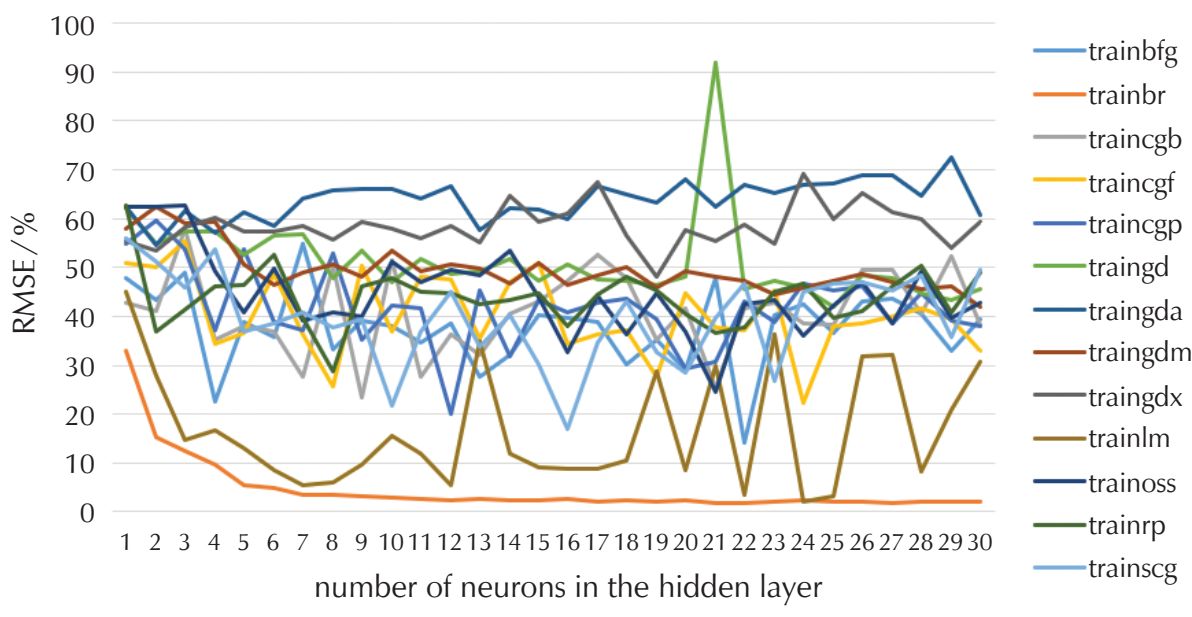

Fig. 2 - Variation of RMSE values of all training algorithms vs. neurons number

was found with a topology of 10-27-2. The second-best algorithm was Levenberg-Marquardt training algorithm with RMSE of $2.1951 \%$ and R-value of $99.9402 \%$ with bad stability. The learning rate was 0.2 as an optimum value, and the momentum was set at 0.5 . The number of epochs was 1000. Table 2 represents the training results based on the min and max RMSE. The other algorithms had fast convergence values, which varied from one to another. Nevertheless, their performances were degraded.

A sensitivity analysis of input variables on the outputs was conducted using weights method; this method was first used by Gar-

Fig. 2 shows the performance of the MLP network trained with 13 algorithms vs the number of neurons in one hidden layer (changed from 1 to 30). Among the tested algorithms, Bayesian regularisation represented in MATLAB by the function trainbr, provided the best results and good stability during the variation of the neuron number with RMSE of $1.7652 \%$, and a coefficient of regression $R=99.9613 \%$

Table 2 - Training algorithms and their ranking

\begin{tabular}{|c|c|c|c|c|}
\hline \multirow{2}{*}{$\begin{array}{l}\text { Matlab } \\
\text { fun }\end{array}$} & \multirow{2}{*}{ Algorithm name } & \multicolumn{2}{|c|}{ RMSE /\% } & \multirow{2}{*}{ Order } \\
\hline & & $\min$ & $\max$ & \\
\hline trainbr & $\begin{array}{l}\text { Bayesian regularization } \\
\text { backpropagation }\end{array}$ & 1.8 & 33.0 & 1 \\
\hline trainlm & $\begin{array}{l}\text { Levenberg-Marquardt } \\
\text { backpropagation }\end{array}$ & 2.2 & 45.0 & 2 \\
\hline trainbfg & $\begin{array}{l}\text { BFGS quasi-Newton } \\
\text { backpropagation }\end{array}$ & 14.0 & 54.8 & 3 \\
\hline trainscg & $\begin{array}{c}\text { Scaled conjugate gradient } \\
\text { backpropagation }\end{array}$ & 16.9 & 56.0 & 4 \\
\hline traincgp & $\begin{array}{l}\text { Conjugate gradient } \\
\text { backpropagation with } \\
\text { Polak-Ribiere updates }\end{array}$ & 20.1 & 59.6 & 5 \\
\hline traincgf & $\begin{array}{c}\text { Conjugate gradient } \\
\text { backpropagation with } \\
\text { Fletcher-Reeves updates }\end{array}$ & 22.2 & 55.5 & 6 \\
\hline
\end{tabular}

son $^{28}$ and Goh. ${ }^{28}$ Weights that correspond to the optimised architecture of $\{10-27-2\}$ with trainbr algorithm were used in this study. Results in Table 3 show that time had a strong effect on both outputs, followed by geographical coordinates of the tested region. Weights and biases are listed in Table 4.

Table 3 - Contributions of different input and output variables

\begin{tabular}{|c|c|c|c|c|}
\hline \multirow{2}{*}{$\begin{array}{l}\text { Matlab } \\
\text { fun }\end{array}$} & \multirow{2}{*}{ Algorithm name } & \multicolumn{2}{|c|}{ RMSE / \% } & \multirow{2}{*}{ Order } \\
\hline & & $\min$ & $\max$ & \\
\hline traincgb & $\begin{array}{l}\text { Conjugate gradient } \\
\text { backpropagation with } \\
\text { Powell-Beale restarts }\end{array}$ & 23.4 & 57.9 & 7 \\
\hline trainoss & $\begin{array}{l}\text { One step secant } \\
\text { backpropagation }\end{array}$ & 24.5 & 62.7 & 8 \\
\hline trainrp & RPROP backpropagation & 28.9 & 62.6 & 9 \\
\hline traingdm & $\begin{array}{l}\text { Gradient descent with } \\
\text { adaptive Ir backpropagation }\end{array}$ & 41.9 & 62.4 & 10 \\
\hline traingd & $\begin{array}{l}\text { Gradient descent } \\
\text { backpropagation }\end{array}$ & 41.9 & 91.8 & 11 \\
\hline traingdx & $\begin{array}{l}\text { Gradient descent w/momentum } \\
\& \text { adaptive Ir backpropagation }\end{array}$ & 48.0 & 69.2 & 12 \\
\hline traingda & $\begin{array}{l}\text { Gradient descent with } \\
\text { adaptive Ir backpropagation }\end{array}$ & 54.5 & 72.6 & 13 \\
\hline
\end{tabular}

\begin{tabular}{c|c|c|c|c|c}
\hline & Outside T & GSR & Emissivity & Nutritional value & Inclination \\
\hline moisture content $/ \%$ & 7.08 & 9.24 & 9.28 & 9.61 & 9.67 \\
\hline drying rate $/ \mathrm{gg}^{-1} \mathrm{~s}^{-1}$ & 7.08 & 9.24 & 9.28 & 9.61 & 9.67 \\
\hline moisture content $/ \%$ & Longitude & Inside T & Altitude & Latitude & 1.09 \\
\hline drying rate $/ \mathrm{gg}^{-1} \mathrm{~s}^{-1}$ & 10.17 & 10.82 & 10.98 & 11.09 & 12.06 \\
\hline
\end{tabular}


Table 4 - Weights and biases of ANN model with the topology of $\{10-27-2\}$

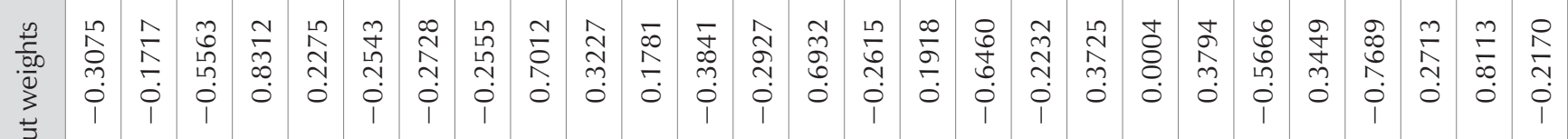

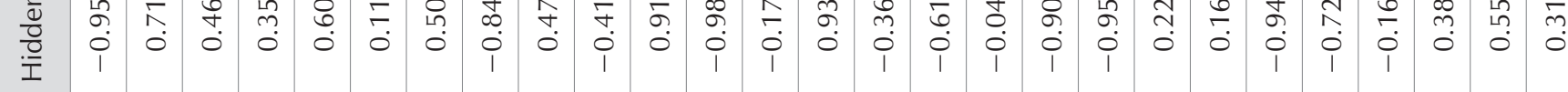

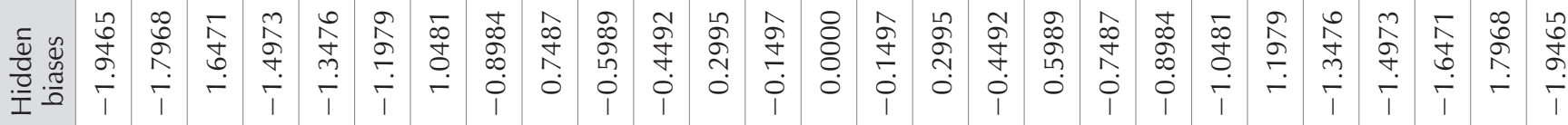

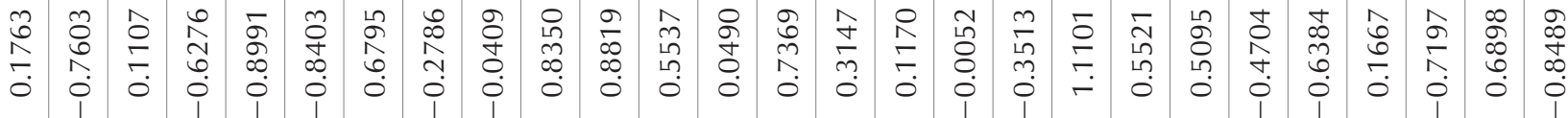

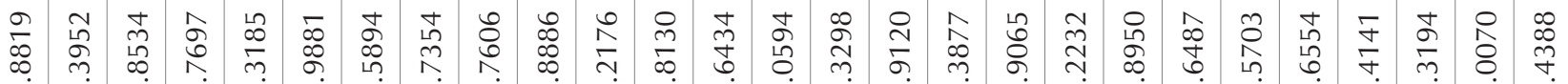
$\begin{array}{lllllllllllllllllllllllllll}i & i & 0 & 0 & i & i & i & i & 0 & i & 0 & 0 & 0 & 0 & 0 & i & 0 & i & i & i & 0 & 0 & 0 & 0 & i & 0 & 0\end{array}$

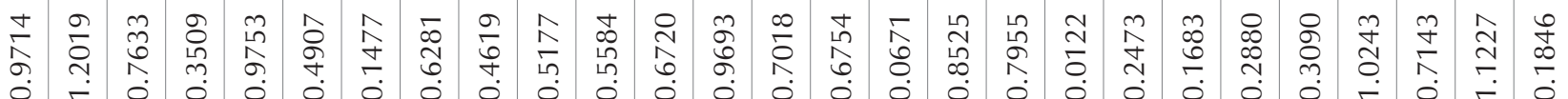

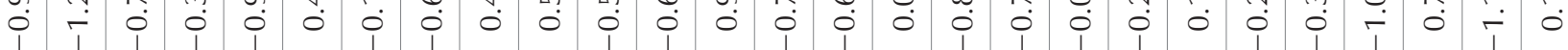

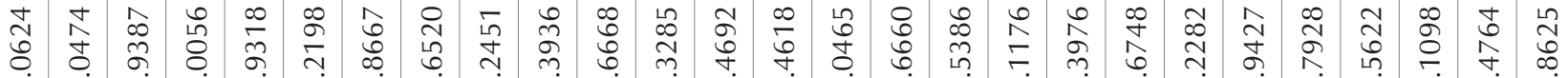



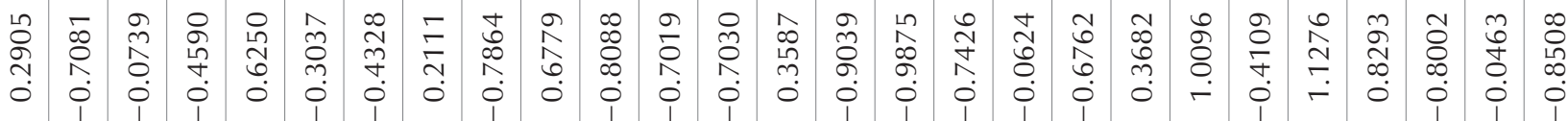



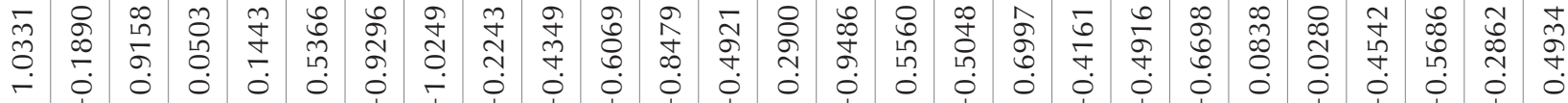

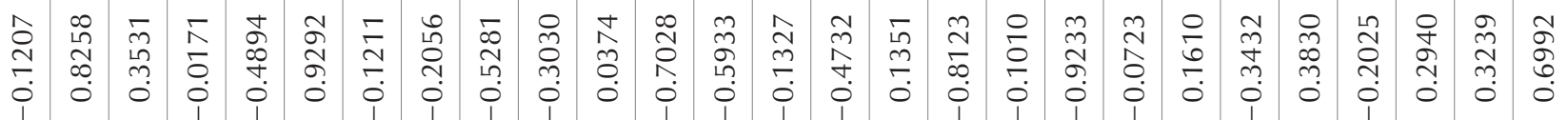

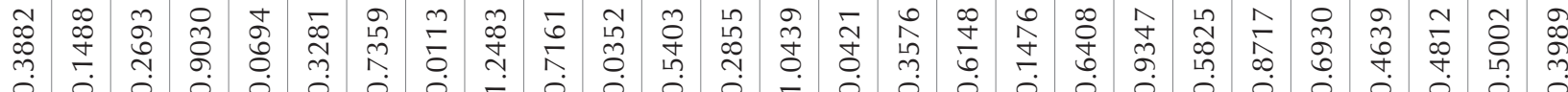

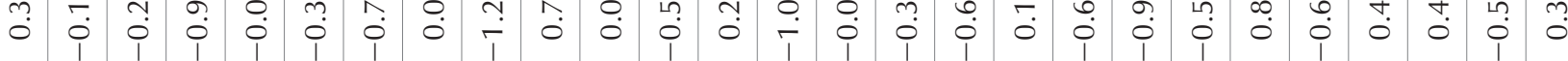




Most authors use only one hidden layer for forecasting purposes. ${ }^{29}$ However, the use of one hidden layer may require a very large number of hidden nodes to achieve the optimal network. Therefore, determination of the optimal number of hidden nodes is a crucial yet complicated step. However, testing two hidden layers with four categories may give better results for some specific problems (Table 5).

The number of neurons in the two layers varied from 1 to 30 under the optimisation of the above parameters. Results presented in Table 6 show that ANN with trainbr algorithm with the architecture of $\{10-28-14-2\}$ using the second distribution of the dataset was able to predict the moisture content $(\mathrm{MC})$ and drying rate (DR) of the final dried products.

Fig. 3 corresponds to the evolution of RMSE vs the number of hidden neurons during the training stage. A plot of the regression of the optimum ANN model with a topology of $\{10-28-14-2\}$ is shown in Fig. 4. Mapping between the target and output data was performed at a satisfactory level because the RMSE was very small (close to zero), and the
$R$-value was close to unity. According to the results shown in Fig. 4, it can be concluded that the ANN algorithm used was very effective in predicting the $M C$ and DR with high correlation and low errors.

\section{Conclusion}

In the present study, an ANN was adopted to develop a uniform and accurate model for simultaneous prediction of the variation of $M C$ and DR of some medicinal plants. Firstly, an ANN model was used with a single hidden layer, which had a favourable network performance, with an $R$-value of $99.9613 \%$ and RMSE of $1.7652 \%$.

The achieved results illustrate the benefit of adding a second hidden layer to improve the performance of the network. The best topology was found with $\{10-28-14-2\}$ with dataset division of $70 \%, 15 \%$, and $15 \%$. The best statistical values obtained for the MC and DR were $R$-values and RMSE values of $97.044 \%$ and $4.589 \%$ and $99.968 \%$,

Table 5 - Percentage of dataset in each category for the global dataset

\begin{tabular}{c|c|c|c|c|c|c|c|c|}
\hline & \multicolumn{4}{|c|}{ Divided dataset } & \multicolumn{3}{c|}{ MC } & \multicolumn{2}{c}{ DR } \\
\cline { 2 - 9 } & Training/\% & Testing/\% & Validation $/ \%$ & RMSE $\%$ & $R / \%$ & RMSE $/ \%$ & $R / \%$ & Topology \\
\hline first category & 80 & 10 & 10 & 7.5092 & 92.3481 & 2.1481 & 99.8947 & $10-23-17-2$ \\
\hline second category & $\mathbf{7 0}$ & $\mathbf{1 5}$ & $\mathbf{1 5}$ & $\mathbf{4 . 5 8 9}$ & $\mathbf{9 7 . 0 4 4}$ & $\mathbf{1 . 1 8 5}$ & $\mathbf{9 9 . 9 6 8}$ & $\mathbf{1 0 - 2 8 - 1 4 - 2}$ \\
\hline third category & 60 & 20 & 20 & 4.4101 & 97.3330 & 1.5964 & 99.9408 & $10-19-27-2$ \\
\hline fourth category & 50 & 25 & 25 & 4.7473 & 97.0397 & 3.2793 & 99.7698 & $10-27-15-2$ \\
\hline
\end{tabular}

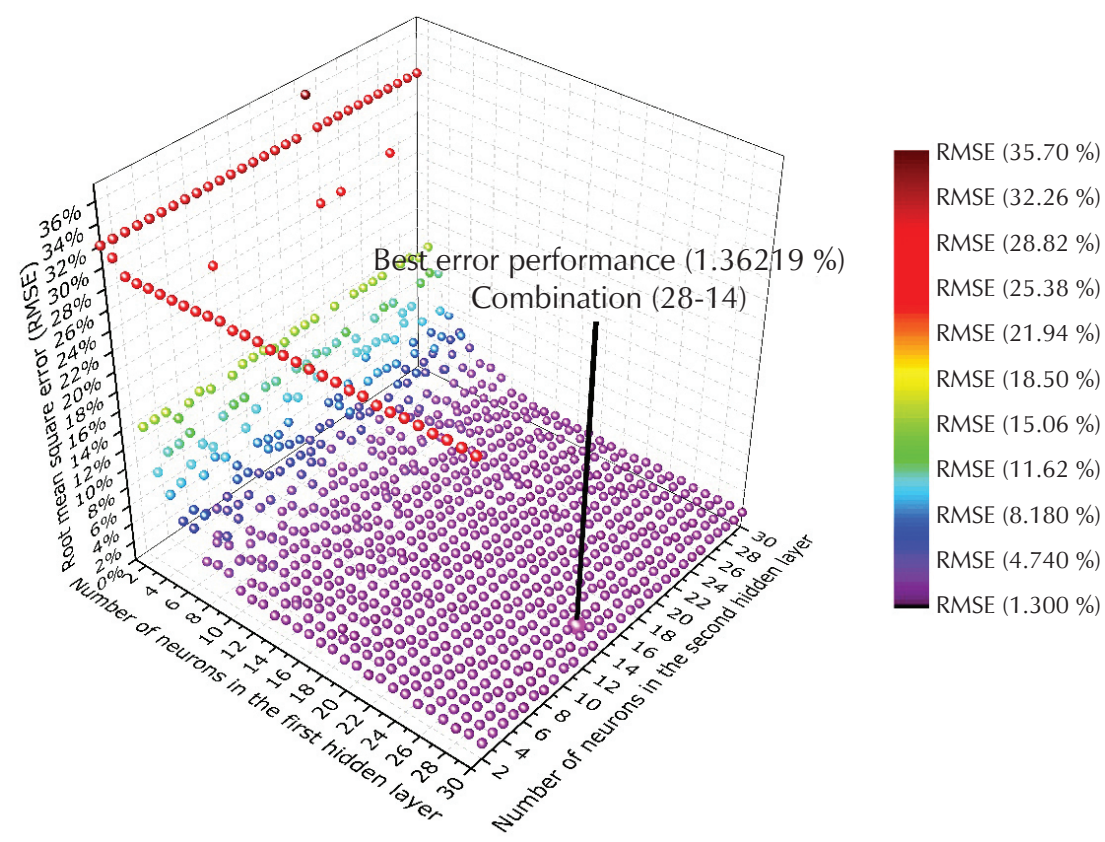

Fig. 3 - Performance of networks vs variation of hidden neurons in the first and second hidden layers 
Drying rate: $R=0.99968$

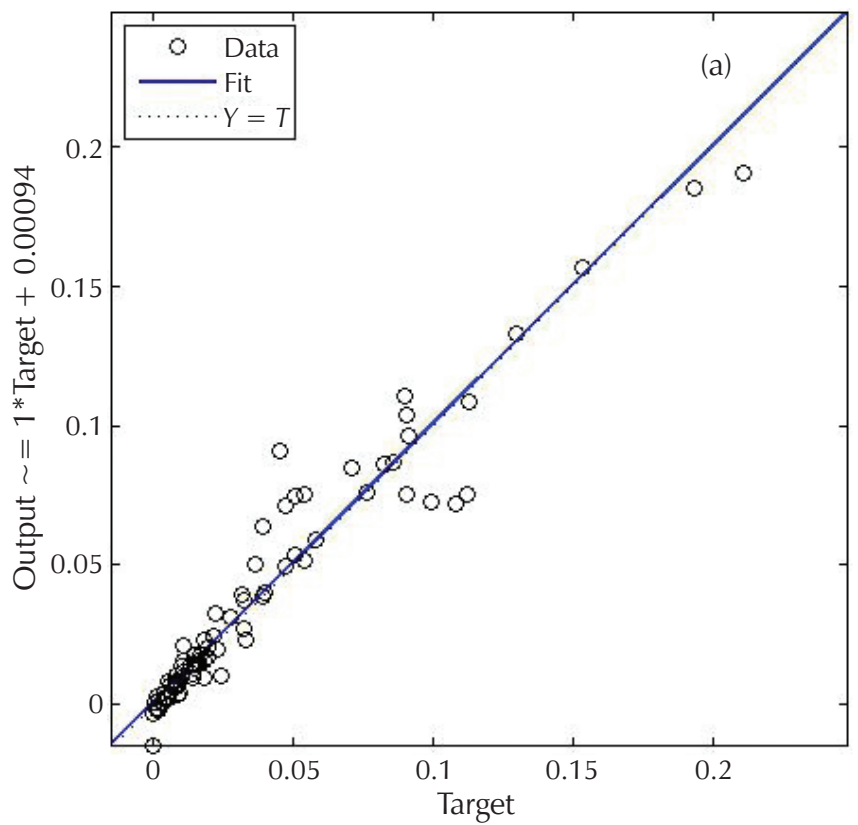

Moisture content: $R=0.97044$

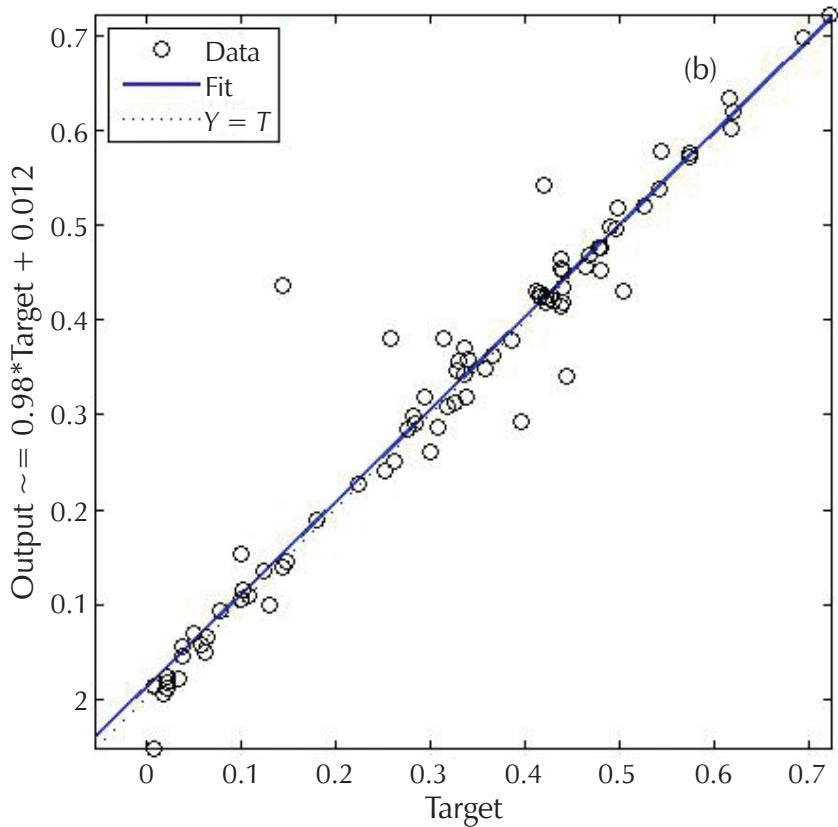

Fig. 4 - Performance of ANN model for moisture content (a); drying rate (b)

and $1.185 \%$, respectively. These results confirmed the ability of the developed ANN model to predict the moisture content and drying rate of medicinal plants such as Mint, Henna, Rosemary, Marjoram, Moghat, Verbena, and Laurel under direct solar drying and open sun drying.

\section{ACKNOWLEDGEMENTS}

Authors wish to thank the Laboratory of Biomaterials and Transport Phenomena, University Yahia Fares of Médéa, Algeria.

\section{References \\ Literatura}

1. T. Gunhan, V. Demir, E. Hancioglu, A. Hepbasli, Mathematical modelling of drying of bay leaves, Energy Convers. Manag. 46 (2005) 1667-1679, doi: https://doi.org/10.1016/j. enconman.2004.10.001.

2. P. P. Tripathy, S. Kumar, Neural network approach for food temperature prediction during solar drying, Int. J. Therm. Sci. 48 (2009) 1452-1459, doi: https://doi.org/10.1016/j. ijthermalsci.2008.11.014.

3. O. Prakash, A. Kumar, Application of artificial neural network for the prediction of jaggery mass during drying inside the natural convection greenhouse dryer, Int. J. Ambiet Energy 35 (2014) 186-192, doi: https://doi.org/https://doi.org/10.1 080/01430750.2013.793455.

4. O. Prakash, A. Kumar, ANFIS modelling of a natural convection greenhouse drying system for jaggery: an experimental validation, Int. J. Sustain. Energy 33 (2014) 316-335, doi: https://doi.org/https://doi.org/10.1080/14786451.2012.724 070.

5. M. n. Ramesh, M. a. Kumar, P. n. Srinivas. Rao, Application of artificial neural networks to investigate the drying of cooked rice, J. Food Process Eng. 19 (1996) 321-329, doi: https:// doi.org/10.1111/j.1745-4530.1996.tb00396.x.

6. A. Balbay, Ö. Şahin, M. Karabatak, An Investigation of Drying Process of Shelled Pistachios in a Newly Designed Fixed Bed Dryer System by Using Artificial Neural Network, Dry. Technol. 29 (2011) 1685-1696, doi: https://doi.org/10.1080/07 373937.2011.600843.

7. A. Khoshhal, A. A. Dakhel, A. Etemadi, S. Zereshki, Artificial Neural Network Modeling of Apple Drying Process, J. Food Process Eng. 33 (2010) 298-313, doi: https://doi. org/10.1111/j.1745-4530.2009.00435.x.

8. F. Karimi, S. Rafiee, A. Taheri-Garavand, M. Karimi, Optimization of an air drying process for Artemisia absinthium leaves using response surface and artificial neural network models, J Taiwan Inst. Chem. Eng. 43 (2012) 29-39, doi: https://doi. org/10.1016/j.jtice.2011.04.005.

9. G. Çakmak, C. Yildiz, The prediction of seedy grape drying rate using a neural network method, Comput. Electron. Agric. 75 (2011) 132-138, doi: https://doi.org/10.1016/j.compag.2010.10.008.

10. A. Topuz, Predicting moisture content of agricultural products using artificial neural networks, Adv. Eng. Soft. 41 (2010) 464-470, doi: https://doi.org/10.1016/j.advengsoft.2009.10.003.

11. N. J. Singh, Neural Network Approaches for Prediction of Drying Kinetics During Drying of Sweet Potato, Agric. Eng. Internat.: CIGR Journal 13 (2011), .

12. S. M. Jadhav, S. L. Nalbalwar, A. Ghatol, Artificial Neural Network based cardiac arrhythmia classification using ECG signal data, in 2010 International Conference on Electronics 
and Information Engineering (2010), pp. V1-228-V1-231, doi: https://doi.org/10.1109/ICEIE.2010.5559887.

13. K. Movagharnejad, M. Nikzad, Modeling of tomato drying using artificial neural network, Comput. Electron. Agric. 59 (2007) 78-85, doi: https://doi.org/10.1016/j.compag.2007.05.003.

14. S. Keskes, S. Hanini, M. Hentabli, M. Laidi, Artificial Intelligence and Mathematical Modelling of the Drying Kinetics of Pharmaceutical Powders, Kem. Ind. 69 (2020) 137-152, doi: https://doi.org/10.15255/KUI.2019.038.

15. N. Melzi, L. Khaouane, Y. Ammi, S. Hanini, M. Laidi, H. Zentou, Comparative Study of Predicting the Molecular Diffusion Coefficient for Polar and Non-polar Binary Gas Using Neural Networks and Multiple Linear Regressions, Kem. Ind. 68 (2019) 573-582, doi: https://doi.org/10.15255/ KUI.2019.010.

16. A. Rezrazi, S. Hanini, M. Laidi, An optimisation methodology of artificial neural network models for predicting solar radiation: a case study, Theor. Appl. Climatol. 123 (2016) 769-783, doi: https://doi.org/10.1007/s00704-015-1398-x.

17. M. Laidi, S. Hanini, A. Rezrazi, M. R. Yaiche, A. A. El Hadj, F. Chellali, Supervised artificial neural network-based method for conversion of solar radiation data (case study: Algeria), Theor. Appl. Climatol. 128 (2017) 439-451, doi: https://doi. org/10.1007/s00704-015-1720-7.

18. M. Kacira, M. Simsek, Y. Babur, S. Demirkol, Determining optimum tilt angles and orientations of photovoltaic panels in Sanliurfa, Turkey, Renew. Energy 29 (2004) 1265-1275, doi: https://doi.org/10.1016/j.renene.2003.12.014.

19. K. V Peter, Handbook of herbs and spices (Woodhead publishing, 2006).

20. C. Pereira, L. Barros, I. C. F. R. Ferreira, A Comparison of the Nutritional Contribution of Thirty-nine Aromatic Plants used as Condiments and/or Herbal Infusions, Plant Food. Hum. Nutr. 70 (2015) 176-183, doi: https://doi.org/10.1007/ s11130-015-0476-7.

21. R. Bhatta, M. Saravanan, L. Baruah, K. t. Sampath, C. s. Pras- ad, Effect of plant secondary compounds on in vitro methane, ammonia production and ruminal protozoa population, J. Appl. Microbiol. 115 (2013) 455-465, doi: https:// doi.org/10.1111/jam.12238.

22. E. K. Akpinar, Drying of mint leaves in a solar dryer and under open sun: Modelling, performance analyses, Energy Convers. Manag. 51 (2010) 2407-2418, doi: https://doi. org/10.1016/j.enconman.2010.05.005.

23. A. A. Hassanain, Unglazed Transpired Solar Dryers for Medicinal Plants, Drying Technol. 28 (2010) 240-248, doi: https://doi.org/10.1080/07373930903530139.

24. Y. I. Sallam, M. H. Aly, A. F. Nassar, E. A. Mohamed, Solar drying of whole mint plant under natural and forced convection, J. Adv. Res. 6 (2015) 171-178, doi: https://doi.org/ https://doi.org/10.1016/j.jare.2013.12.001.

25. R. Miri, O. Mokrani, F. Siad, M. Belhamel, Etude expérimentale d'un séchoir solaire, Revue Des Énergies Renouvelables (2002) 41-48,

26. M. Aghbashlo, S. Hosseinpour, A. S. Mujumdar, Application of Artificial Neural Networks (ANNs) in Drying Technology: A Comprehensive Review, Drying Technol. 33 (2015) 1397 1462, doi: https://doi.org/10.1080/07373937.2015.103628 8.

27. N. O. Attoh-Okine, Analysis of learning rate and momentum term in backpropagation neural network algorithm trained to predict pavement performance, Adv. Eng. Soft. 30 (1999) 291-302, doi: https://doi.org/10.1016/S09659978(98)00071-4.

28. A. Nicholas Refenes, A. Zapranis, G. Francis, Stock performance modeling using neural networks: A comparative study with regression models, Neural Networks 7 (1994) 375-388, doi: https://doi.org/10.1016/0893-6080(94)90030-2.

29. T. Thyagarajan, J. Shanmugam, R. C. Panda, M. Ponnavaikko, P. G. Rao, Artificial neural networks: Principle and application to model based control of drying systems - a review, Dry. Technol. 16 (1998) 931-966, doi: https://doi. org/10.1080/07373939808917449. 


\title{
SAŽETAK
}

\section{Novi pristup u predviđanju izravnog i otvorenog solarnog sušenja pomoću umjetne neuronske mreže za ljekovito bilje}

\author{
Ahmed Sadadou, Salah Hanini, Maamar Laidi* i Ahmed Rezrazi
}

\begin{abstract}
U ovom istraživanju razvijena je umjetna neuronska mreža (ANN) za dobivanje uopćenog modela za predviđanje izravnog i otvorenog postupka solarnog sušenja za određene ljekovite biljke. Budući da kvaliteta eksperimentalnog skupa podataka može dovesti do modela visoke izvedbe, u ovoj je studiji skup podataka prikupljen iz prethodno objavljenih radova i nasumce podijeljen u tri podskupine - $70 \%$ za trening, $15 \%$ za testiranje i $15 \%$ za validaciju. Na temelju složenog postupka solarnog sušenja, za predviđanje sadržaja vlage (SV) i brzine sušenja (BS) uzima se deset ulaznih parametara: vrijeme, globalno sunčevo zračenje (GSZ), vanjska temperatura, nagib, emisivnost, nadmorska visina, zemljopisna dužina, zemljopisna širina, unutarnja temperatura i hranjiva vrijednost. Na temelju metode pokušaja i pogreške, pronađen je najbolji model ANN s topologijom 10-28-14-2 te koeficijentom regresije i srednjom kvadratnom pogreškom od $(R=97,044 \%$, RMSE $=4,589 \%)$ za SV i $(R=99,968 \%$, RMSE $=1,185 \%)$ za BS. Može se zaključiti da je dobiveni ANN najbolji model za modeliranje solarnih sušilica koji se može generalizirati za bilo koje mjesto na svijetu.
\end{abstract}

Ključne riječi

Umjetna neuronska mreža, ljekovita biljka, solarno sušenje, sadržaj vlage, brzina sušenja

Biomaterials and Transport Phenomena Laboratory, University of Yahia Fares Médéa, Alžir
Izvorni znanstveni rad Prispjelo 13. srpnja 2020. Prihvaćeno 26. kolovoza 2020. 